JURNAL RISET KESEHATAN NASIONAL

VOL. 4 NO. 2 Halaman 67-72

$P$ - ISSN : 2580-6173

E-ISSN : 2548-6144

Available Online http://ojs.itekes-bali.ac.id/index.php/jrkn/index

\title{
HUBUNGAN TINGKAT PENGETAHUAN MASYARAKAT TENTANG HIV/ AIDS DENGAN STIGMA TERHADAP ODHA DI WILAYAH KERJA PUSKESMAS II DENPASAR SELATAN
}

\section{(Correlation between level of public knowledge about HIV/AIDS and stigma the people with HIV / AIDS at Puskesmas II Denpasar Selatan)}

\author{
A.A.Ayu Yuliati Darmini ${ }_{* * *)}^{*}$ Jeanne ValentinaNatassa Bely ${ }^{* * *}$ \\ ${ }^{* * *)}$ Institut Teknologi dan Kesehatan Bali \\ E-mail : yddarmini@gmail.com
}

\begin{abstract}
ABSTRAK
Latar Belakang: HIV/AIDS adalah suatu penyakt infeksi dimana sampai sat ini belum ditemukan obat yang bisa menyembuhkan penyakit ini. Dalam 6 tahun terakhir penyakit ini meningkat pesat di seluruh dunia maupun di Indonesia. Orang dengan HIV AIDS sering mendapatkan stigma di masyarakat. Tujuan penelitian ini adalah untuk mengetahui hubungan antara tingkat pengetahuan tentang HIV/AIDS dengan Stigma pada penderita dengan HIV/AIDS.

Metode: Desain penelitian adalah diskriptive korelasi dengan pendekatan crossectional. Dengan simple random sampling sebanyak 100 orang direkrut sebagai responden. Data dikumpulkan menggunakan kuisioner dan dianalisis dengan menggunakan tekhnik statistic Spearman Rho pada SPSS versi 20.

Hasil: Hasil menunjukkan sebanyak 79\% responden memiliki pengetahuan baik, dan $85 \%$ responden memliki stigma dengan katagori rendah. Terdapat hubungan yang significant dengan arah korelasi negative antara tingkat pengetahuan dengan stigma (pvalue $=0,001$ : $\mathrm{r}=-0,543$ )

Kesimpulan: Tingkat pengetahuan masyarakat tentang HIV/AIDS menentukan stigma di masyarakat. Makin baik pengetahuan makin rendah stigma dimasyarakat. Diharapkan masyarakat mengikuti perkembangan HIV/AIDS melalui informasi yang terkini sehingga dapat menekan stigma yang terjadi pada penderita HIV/AIDS.
\end{abstract}

Kata kunci: Pengetahuan, Stigma, ODHA

\section{ABSTRACT}

Background: HIV/AIDS is one of an infected disease that until now days, there is not an effective medicine found to cure these diseases. At the last six years, this disease shows an increasing rapidly both in the world or Indonesia either. Mostly the people with HIV/AIDS got stigma. Purpose: To determine the correlation between level of public knowledge about HIV / AIDS and stigma the people with HIV / AIDS

Method: The study was descriptive correlational design with cross-sectional approach. About 100 respondents of samples were taken by simple random sampling technique, Data were collected by using a questionnaire and analyze by Spearman Rho statistical test with SPSS 20 version.

Result: The study found that about 79\% respondents were classified into good category, 
level of knowledge and 85\% respondents were classified into low level of sigma. There was a statistically negative correlation between level of knowledge and stigma patient with HIV/AIDS. ( $p=0,001: r=-0,543)$.

Conclusion: Community level of knowledge has a closed correlation with stigma. The higher level of knowledge the low level of stigma. The community need find more information about HIV/AIDS in other to decrease stigma of people with HIV/AIDS.

Keywords: Knowledge, Stigma, HIV/AIDS

\section{LATAR BELAKANG}

The human immunodeficiencyvirus (HIV) adalah retrovirus yang menginfeksi sel sistem kekebalan tubuh, menghancurkan atau merusak fungsi mereka. Saat infeksi berlangsung, sistem kekebalan tubuh menjadi lemah, dan orang menjadi lebih rentan terhadap infeksi (WHO, 2015).Insiden HIV dan AIDS di Indonesia saat ini menunjukkan peningkatan yang sangat fantastis, hal ini ditunjukkan dalam jangka waktu 6 tahun jumlah orang dengan HIV dan AIDS (ODHA) meningkat 6 kali lipat(Waluyo, Nova, \& Edison, 2007).

Ketidaktahuan masyarakat tentang mekanisme penularan HIV, dan masih banyak masyarakat menganggap bahwa penularan HIV bisa terjadi melalui kontak biasa yang menyebabkan banyak perlakuan yang tidak adil terhadap ODHA salah satunya adalah stigma. Masalah stigma dimasyarakat semakin tinggi terutama dari lingkungan individual (ODHA itu sendiri), lingkungan keluarga dan lingkungan komunitas (masyarakat). Stigma terkait ODHA adalah segala persangkaan, penghinaan dan diskriminasi yang ditunjukkan oleh individu, kelompok atau komunitas yang berhubungan dengan ODHA tersebut(Nurhayati, 2013). Secara langsung maupun tidak langsung stigma dapat berakibat buruk pada ODHA dan mengakibatkan penurunan cakupan terapi HIV dan AIDS yang dijalani oleh pasien ODHA (Waluyo et al., 2007).

Stigma pada ODHA melekat kuat karena tingkat pengetahuan masyarakat tentang HIV/ AIDS dan ODHA itu sendiri masih kurang, dan masyarakat masih memegang teguh nilainilai moral, agama, dan budaya atau adat istiadat ketimuran (Indonesia) dimana masyarakat menganggap orang yang terkena HIV/AIDS disebabkan oleh perilaku yang dekat dengan narkoba, seks bebas dan sebagainya, sehingga jika virus ini menginfeksi seseorang maka dianggap sebagai akibat dari perilaku yang merugikan dirinya sendiri. Maka dari itu masyarakat menjauhi dan mencibir ODHA karena menganggap ODHA sebagai sosok yang menakutkan.

Menurut data yang diperoleh dari infodatin AIDS (2015) jumlah ODHA diIndonesia pada tahun 2014 mencapai 22.869 orang. Dari jumlah tersebut Bali menjadi peringkat ke empat jumlah ODHA terbanyak. Jumlah ODHA di Bali dari tahun ke tahun menunjukkan peningkatan yang cukup pesat, pada tahun 2014 jumlah ODHA di Bali sebanyak 2.221 orang (Dinas Kesehatan Provinsi, 2015).

Setyoadi dalam Harefa (2012) juga mengatakan stigma dimasyarakat terkait penularan penyakit HIV/AIDS masih berkembang. Salah satu contohnya kasus penderita HIV/AIDS yang dikucilkan oleh masyarakat dengan cara dibuatkan rumah di pinggiran desa yang sangat tidak layak, keluarga juga tidak mau menerima keberadaan mereka dan tidak mengakui sebagai anggota keluarga. Adanya pasangan yang suaminya meninggal karena HIV/AIDS kemudian istri dan keluarganya dijauhi oleh masyarakat dan diusir dari desa dan adanya anak yang dikeluarkan dari sekolah yang didapati positif HIV serta anak usia sekolah yang tidak diterima masuk sekolah disebabkan ibunya menderita HIV/AIDS.

HIV/AIDS merupakan isu kesehatan yang cukup sensitif untuk dibicarakan. Kasusnya diumpamakan seperti gunung es, yang terungkap sedikit namun sangat banyak yang masih tersembunyi. Berdasarkan laporan dari tahun ke tahun menunjukkan peningkatan yang signifikan. Menurut laopran WHO (World Health Organization) 2009, 33,3 juta orang hidup dengan HIV dan 1,8 juta orang meninggal karenanya.

\section{METODE PENELITIAN}

Desain penelitian yang digunakan adalah deskriptif correlation dengan pendekatan cross-sectional study. Pendekatan crosssectional adalah design penelitian yang pengumpulan datanya dilakukan dalam satu 
titik waktu (at one point in time): fenomena yang diteliti adalah selama satu periode pengumpulan data (Swarjana, 2013). Pengumpulan data dilakukan di wilayah kerja Puskesmas II Denpasar Selatan. Populasi dalam penelitian ini yaitumasyarakat di wilayah kerja Puskesmas II Denpasar Selatan. Jumlah sampel penelitian ini sebanyak 100 orang. Pengambilan sampel pada penelitian ini menggunakan probability sampling dengan menggunakan teknik simple random sampling.

Dalam penelitian ini peneliti menggunakan kuesioner pengetahuan masyarakat tentang HIV/AIDS dan stigma terhadap ODHA..Kuesioner ini sudah dilakukan uji validitas denan menggunakan face validity oleh 2 orang expert dibidangnya. Sebelum melakukan pengumpulan data, peneliti memperkenalkan diri terlebih dahulu, kemudian peneliti menjelaskan tujuannya datang kerumah responden, setelah itu peneliti memberikan lembar persetujuan (informed consent), kemudian peneliti menjelaskan cara mengisi kuisioner yang diberikan.Setelah data diperoleh kemudian peneliti melakukan pengolahan data menggunakan program komputer SPSS 20 for windows. Analisa data yang digunakan dalam penelitian ini yaitu uji SpearmanRho.

\section{HASIL}

\section{Karakteristik Responden}

Setelah data terkumpul dari masyarakat mengenai Hubungan Tingkat Pengetahuan Masyarakat Tentang HIV/AIDS Dengan Stigma Terhadap ODHA di wilayah kerja Puskesmas II Denpasar Selatan yang melibatkan 100 responden, selanjutnya dilakukan pengolahan data yang melalui coding dan data entry pada SPSS 20 for windows. Tidak ada missing data pada penelitian ini.Hasil penelitian akan ditampilkan sebagai berikut.

Tabel 1.

Karakteristik responden berdasarkan umur, jenis kelamin, agama, pekerjaan, dan pendidikan pada Masyarakat wilayah kerja

Puskesmas II Denpasar Selatan $(\mathrm{n}=100)$

\begin{tabular}{lll}
\hline $\begin{array}{l}\text { KarakteristikRe- } \\
\text { sponden }\end{array}$ & Frekuensi & $\begin{array}{l}\text { Persen- } \\
\text { tase (\%) }\end{array}$ \\
Umur & & \\
$17-25$ tahun & 49 & 49 \\
$26-35$ tahun & 18 & 18 \\
$36-45$ tahun & 33 & 33 \\
JenisKelamin & & \\
Laki-laki & 44 & 44 \\
Perempuan & 56 & 56 \\
Agama & 94 & 94 \\
Hindu & 6 & 6 \\
Islam & & \\
Pekerjaan & 4 & 4 \\
PNS & 60 & 60 \\
Swasta/Wiraswata & 28 & 28 \\
Pelajar & 8 & 8 \\
Tidak Bekerja & & \\
& & 1 \\
Pendidikan & 1 & 6 \\
SD & 6 & 42 \\
SMP & 42 & 51 \\
SMA & 51 & \\
Perguruan Tinggi & & \\
\hline
\end{tabular}

Berdasarkan tabel di atas dapat dijelaskan bahwa dari 100 responden sebagian besar responden berumur 17-25 tahun sebanyak $49 \%$, berjenis kelamin perempuan sebanyak $56 \%$, beragama hindu sebanyak 94\%, sebagian besar responden bekerja sebagai swasta/wiraswasta $60 \%$ dan sebagian besar responden berpendidikan perguruan tinggi yaitu sebanyak $51 \%$.

Tabel 2.

Distribusi frekuensi berdasarkan tingkat pengetahuan masyarakat tentang HIV/AIDS di wilayah kerja Puskesmas II Denpasar Selatan $(n=100)$

\begin{tabular}{lll}
\hline $\begin{array}{l}\text { Penge- } \\
\text { tahuan }\end{array}$ & Frekuensi & $\begin{array}{l}\text { Persentase } \\
(\%)\end{array}$ \\
Baik & 79 & 79 \\
Cukup & 15 & 15 \\
Kurang & 6 & 6 \\
\hline
\end{tabular}

Dari tabel diatas menjelaskan bahwa mayoritas responden mempunyai pengetahuan dalam katagori baik yaitu sebanyak $79 \%$.

Tabel 3.

Distribusi frekuensi berdasarkan stigma masyarakat terhadap ODHA di wilayah kerja Puskesmas II Denpasar Selatan $(\mathrm{n}=100)$. 


\begin{tabular}{lll}
\hline Stigma & Frekuen- & Persentase (\%) \\
& si & \\
Tinggi & 2 & 2 \\
Sedang & 13 & 13 \\
Rendah & 85 & 85 \\
\hline
\end{tabular}

Tabel 3 menunjukkan bahwa sebagian besar responden memiliki stigma rendah terhadap ODHA yaitu sebanyak $85 \%$.

Tabel 4.

Tabel korelasi Spearmen Rho tingkat pengetahuan masyarakat tentang HIV/AIDS dengan stigma masyarakat terhadap ODHA $(\mathrm{n}=100)$.

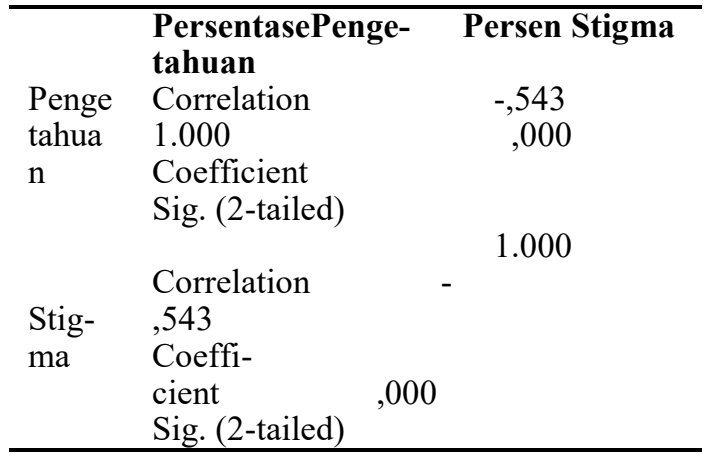

Berdasarkan tabel diatas diperoleh hasil analisis korelasi dengan 0,001 yang berarti Ha diterima. Hal ini menunjukkan bahwa ada hubungan antara Tingkat Pengetahuan Masyarakat Tentang HIV/AIDS dengan Stigma Masyarakat Terhadap ODHA yang memiliki kekuatan hubungan cukup kuat (. Hubungan dari kedua variabel tersebut kearah negatif yang berarti semakin baik pengetahuan masyarakat maka semakin rendah stigma masyarakat terhadap ODHA.

\section{PEMBAHASAN}

\section{Tingkat PengetahuanMasyarakatTentang HIV/AIDS}

Dari hasil penelitian yang peneliti lakukan menunjukkan bahwa lebih dari setengah responden berpengetahuan baik yaitu sebanyak $79 \%$ responden, sebanyak $15 \%$ responden mempunyai pengetahuan cukup dan sisanya sebanyak $6 \%$ responden mempunyai pengetahuan kurang. Hal ini disebabkan karena dari 100 responden yaitu sebanyak 97\% mengetahui AIDS disebabkan oleh virus HIV (Human Immunodeficiency Virus), 90\% mengetahui penggunaan jarum suntik yang bergantian dan tidak steril dapat menyebabkan HIV/AIDS, 92\% mengetahui HIV/AIDS dapat dicegah dengan tidak melakukan hubungan seks bagi yang belum menikah, dan 96\% mengetahui bahwa penggunaan kondom dapat mengurangi resiko terinfeksi HIV/AIDS, tetapi dari hasil yang di dapat masih ada masyarakat yang memeiliki pengetahuan kurang, hal ini disebabkan $55 \%$ responden menjawab ibu yang positif HIV tidak akan menularkan HIV kepada janin yang dikandungnya.Hal ini sejalan dengan penelitian yang dilakukan oleh Tulung (2014) tentang hubungan antara pengetahuan dan sikap dalam pencegahan HIV/AIDS pada siswa menunjukkan hasil yang sama yaitu pengetahuan siswa tentang HIV/AIDS dan pencegahannya lebih banyak berada di kategori baik yaitu sebanyak $73,3 \%$, hal ini disebabkan $97,8 \%$ responden mendapat informasi tentang HIV/AIDS dari guru dan kategori tidak baik sebanyak 26,7\% disebabkan karena responden sebanyak 2,2\% tidak mendapat informasi dari guru.

\section{Stigma Masyarakat Terhadap ODHA}

Dari hasil penelitian yang dilakukan oleh peneliti menunjukkan bahwa stigma masyarakat terhadap ODHA adalah rendah. Sebanyak $85 \%$ responden memiliki stigma rendah terhadap ODHA, sebanyak 13\% responden memiliki stigma sedang dan sebanyak $2 \%$ responden memiliki stigma tinggi. Hal ini disebabkan karena dari 100 responden yaitu sebanyak $50 \%$ tidak setuju jika ODHA tidak boleh hidup atau menetap dilingkungan masyarakat, 57\%mengatakan tidak setuju jika ODHA tidak memerlukan dukungan keluarga untuk kesembuhannya, $56 \%$ mengatakan tidak setuju jika ODHA tidak boleh bergaul dengan masyarakat dan $50 \%$ mengatakan tidak setuju jika ODHA tidak boleh bergaul dengan masyarakat, tetapi dilihat dari hasil masih ada responden yang menstigma ODHA dikarenakan 47\% responden menjawab bahwa ODHA adalah seseorang yang berbeda dari masyarakat lainnya dan $45 \%$ responden menjawab sangat tidak setuju jika ODHA perlu diajak atau dirangkul dalam organisasi masyarakat.Hasil penelitian ini juga didukung dengan penelitian yang dilakukan oleh Nurhayati (2012) menyatakan bahwa stigma dilingkungan masyarakat saat ini telah banyak menunjukkan perubahan kearah yang lebih baik dibandingkan tahun-tahun sebelumnya hal ini disebabkan masyarakat saat ini telah menerima ODHA sebagai bagian dari komunitas. Pernyataan ini diperkuat oleh pengakuan beberapa ODHA yang sudah mau membuka statusnya kepada 
masyarakat menyatakan bahwa mereka tidak lagi menemukan kesulitan untuk berbaur dan bersosialisasi dengan masyarakat.

\section{Hubungan Tingkat Pengetahuan Masyarakat Tentang HIV/AIDS Dengan Stigma Terhadap ODHA \\ Dari hasil analisis menggunakan SPSS} For Windows 20 di dapat hasilnya menunjukkan ada hubungan yang kuat antara tingkat pengetahuan masyarakat tentang HIV/ AIDS dengan stigma terhadap ODHA dengan korelasi negatif sedang yang artinya semakin baik tingkat pengetahuan masyarakat maka semakin rendah juga stigma masyarakat terhadap ODHA.

Penelitian ini sejalan dengan penelitian yang dilakukan oleh Mardhatillah (2015) yaitu responden dengan pengetahuan cukup lebih banyak yang tidak memiliki stigma terhadap ODHA dibanding dengan responden dengan pengetahuan kurang. Ada hubungan antara pengetahuan siswa tentang HIV/AIDS dengan stigma terhadap orang dengan HIV/ AIDS di SMAN 5 Makassar.Penelitian lain yang mendukung hasil penelitian ini adalah penelitian yang dilakukan oleh Sosodoro (2009) tentang hubungan pengetahuan tentang HIV/AIDS dengan stigma orang dengan HIV/AIDS dikalangan pelajar SMA yaitu responden dengan pengetahuan yang baik tidak memiliki stigma terhadap ODHA. Jadi terdapat hubungan yang bermakna antara pengetahuan dengan stigma terhadap ODHA.

\section{KESIMPULAN}

Berdasarkan tujuan umum dan tujuan khusus mengenai hubungan tingkat pengetahuan masyarakat tentang HIV/AIDS dengan stigma terhadap ODHA di wilayah kerja Puskesmas II Denpasar Selatan, maka dapat disimpulkan sebagai berikut: lebih dari setengah responden memiliki pengetahuan baik yaitu sebanyak $79 \%$, sebagian besar masyarakat memiliki stigma rendah terhadap ODHA yaitu sebanyak $85 \%$, dan hasil analisis menunjukkan ada hubungan antara tingkat pengetahuan masyarakat tentang HIV/ AIDS dengan stigma terhadap ODHA dengan korelasi negatif sedang yang artinya semakin baik tingkat pengetahuan masyarakat maka semakin rendah juga stigma masyarakat terhadap ODHA.

\section{DAFTAR PUSTAKA}

Afrianty, F. (2013). Stigma dan Diskriminasi Terhadap ODHA, Tugas dan Tanggung jawab Siapa? Diperoleh tanggal 15 Oktober 2015, dari http:// kebijakanaidsindonesia.net/id/ beranda/20-artikel article/ kontribusi/1005-stigma-dandiskriminasi-terhadap-odha-tugas-dantanggungjawab-siapa.

Ahwan, Z. (2013). Stigma dan diskriminasi HIV \& AIDS pada Orang denganHIV dan AIDS (ODHA) di masyarakat basis anggota Nahdlatul Ulama (NU) Bangil. Diperoleh tanggal 15 Oktober 2015, dari http://jurnal.yudharta.ac.id/wpcontent/uploads/2014/11/11.pdf.

Ardhiyanti, Lusiana, M. (2015). Bahan Ajar AIDS Pada Asuhan Kebidanan. Sleman: Deepublish Plubisher.

Ariani, P. A. (2014). Aplikasi Metodologi Penelitian Kebidanan dan Kesehatan Reproduksi. Yogyakarta: Nuha Medika.

Aspuah, S. (2013). Kumpulan Kuesioner Instrumen Penelitian Kesehatan. Yogyakarta: Nuha Medika.

Dinas Kesehatan Provinsi Bali. (2015). Situasi Kasus HIV/AIDS di Provinsi Bali. Bali : Dinas Kesehatan Provinsi Bali.

Dinas Kesehatan Kota Denpasar. (2015). Situasi Kasus HIV/AIDS di Kota Denpasar. Denpasar : Dinas Kesehatan Kota Denpasar.

Harefa, K. (2012). Hubungan Dukungan Keluarga Dengan Harga Diri Orang HIV/AIDS (ODHA) di Lembaga Medan Plus Medan Tahun 2012. Diperoleh tanggal 15 Oktober 2015, dari https://www.google.co.id/url? $\mathrm{sa}=\mathrm{t} \& \mathrm{rct}=\mathrm{j} \& \mathrm{q}=\&$ esrc $=\mathrm{s} \&$ source $=$ web $\&$ $\mathrm{cd}=1 \& \mathrm{cad}=$ rja \&uact $=8 \& \mathrm{Ved}=0$ ahukew iakuruy4pnahwbmzqkhxfgcigqfggamaa $\& \mathrm{Url}=\mathrm{Http} \% 3 \mathrm{~A} \% 2 \mathrm{~F} \% 2 \mathrm{Fsari}-$

Mutiara.Ac.Id\%2Fnew\%2Fwpcontent $\% 2$ Fuploads $\% 2$ F $2013 \% 2$ F $11 \%$ 2F42-Hubungan-Dukungan-KeluargaDengan-Harga-Diri-Orang-

HIV.Doc\&Usg=Afqjenfqpxdlb_F7lxqc 0r5slrfqdxyibw.

Hidayat, A. (2008). Riset Keperawatan dan Teknik Penulisan Ilmiah (2nd ed.). Jakarta: Salemba Medika.

Hidayat, A. (2010). Metode Penelitian Kesehatan. Surabaya: Health

Jurnal Riset Kesehatan Nasional hal. 71 
Books Publishing.

Irianto, K. (2014). Seksologi Kesehatan. Bandung: Alfabeta.

Mardhatillah. (2015) Hubungan Pengetahuan dan Sikap Siswa Tentang HIV dan AIDS Dengan Stigma Terhadap Orang Dengan HIV/AIDS (ODHA) di SMAN 5 Makassar. Diperoleh tanggal 16 Mei 2016, dari http:// repository.unhas.ac.id:4001/digilib/ files/disk1/314/--mardhatill-15691-1mardhati-).pdf.

Maryunani, A. (2009). Pencegahan Penularan HIV Dari Ibu Ke Bayi. Trans Info Media.

Mubarak, Chayatin, S. (2009). Ilmu Keperawatan Komunitas (2nd ed.). Salemba Medika.

Notoatmodjo, S. (2007). Kesehatan Masyarakat Ilmu \& Seni. Jakarta: PT RINEKA CIPTA.

Notoatmodjo, S. (2010). Ilmu Perilaku Kesehatan. Jakarta: PT RINEKA CIPTA.

Nurbani, F. (2009). Dukungan Sosial Pada ODHA. Diperoleh tanggal 14 Oktober 2015, dari http:// www.gunadarma.ac.id/library/articles/ graduate/psychology/2009/

Artikel 10503068.pdf.

Nurhayati, $\bar{E}$. (2013). Stigma dan Diskriminasi Terhadap ODHA di Kota Bandung, 1-10 Diperoleh tanggal 14 Oktober 2015.

Nursalam. (2008). Konsep dan Penerapan Metodologi Penelitian Keperawatan (2nd ed.). Jakarta: Salemba Medika.

Prasetyawati, E. (2011). Ilmu Kesehatan Masyarakat. Nuha Medika.

Pusat Data Dan Informasi Kementerian Kesehatan Republik Indonesia. (2015) Situasi dan Analisis HIV/AIDS. Jakarta : Kementerian Kesehatan Republik Indonesia.
Silalahi, C. (2013). Hubungan antara pengetahuan dan sikap perawat tentang HIV/AIDS dengan tindakan perawat terhadap penderita HIV/AIDS di rumah sakit Pancaran Kasih Manado. Diperoleh tanggal 16 Mei 2016, dari http://fkm.unsrat.ac.id/wpcontent/uploads/2013/08/JurnalChristine-Silalahi-09.pdf.

Sofro, M. (2015). Sehat dan Sukses dengan HIV/AIDS. Jakarta: PT Elex Media Komputindo.

Sosodoro, O. (2009). Hubungan Pengetahuan Tentang Hiv / Aids Dengan Stigma Orang Dengan Hiv / Aids Di Kalangan Pelajar Sma Relationship Between Knowledge About HIV / AIDS And Stigma Of People, 25(4), 210-217. Diperoleh tanggal 14 Oktober 2015.

Sugiyono. (2014). Metode Penelitian Kuantitatif Kualitatif dan R\&D. Alfabeta.

Swarjana, K. (2013). Metodologi Penelitian Kesehatan (1st ed.). Yogyakarta: CV Andi Offset.

Tulung, O. (2014). Hubungan antara pengetahuan dan sikap dengan tindakan pencegahan HIV/AIDS pada siswa SMK Negeri 1 Tomohon. Diperoleh tanggal 16 Mei 2016, dari http://fkm.unsrat.ac.id/wp-content/ uploads/2014/10/Vane-Jurnal.pdf.

Waluyo, A., Nova, P. A., \& Edison, C. (2007). Perilaku Perawat Terhadap Orang Dengan HIV / AIDS. Diperoleh tanggal 15 Oktober 2015.

WHO. (2015). HIV/AIDS. Diperoleh tanggal 15 Oktober 2015, dari http:// www.who.int/topics/hiv aids/en/

Wawan A, dan Dewi, M. (2010). Teori Dan Pengukuran Pengetahuan, Sikap, Dan Perilaku Manusia. Yogyakarta: Nuha Medika. 